\title{
Health Care Reforms and the Challenge of INEQUALITY FROM A HUMAN RIGHTS LENS: LESSONS FROM EUROPE
}

\author{
Elisavet Athanasia AleXiadou, PhD, LLM, MSc*
}

\begin{abstract}
Over the last decade, in the European health landscape, several countries have adopted laws that impose health care reforms which entail the gradual implementation of structural reform, primarily cost-containment, measures and a privatization agenda in the health sector in order to curtail financial deficits. At the same time, however, socioeconomic health inequalities have raised dramatically, which in turn constitutes a serious area of human rights concern across Europe. In fact, a growing number of individuals, especially those in vulnerable population groups, seem to encounter considerable impediments in accessing health care which is of decisive influence in terms of health outcomes. Arguably, this disturbing development creates tension with human rights values, while it alludes that a human rights dimension might be completely absent from the formulation of health care reforms. Following that, this article uses a human rights lens through which to examine the intersection between human rights commitments and imposed health care reforms. Finally, as a way of addressing current and future imbalances in health care that generate inequality, the article concedes that health care reforms should be designed and implemented not in isolation from, but in consistency with human rights requirements and particularly with the right to health requirements.
\end{abstract}

\section{INTRODUCTION}

In recent years, the European health landscape has witnessed a remarkable surge of health care reforms primarily prompted by the Eurozone crisis and its associated fiscal pressure on several European Union (EU) member states to alleviate public deficits and restore economic growth. ${ }^{1}$ The practical consequence of this development, along with the fact that health expenditure in most European countries was associated with significant amounts of public spending, meant that the latter has become a niche area, attracting the focused attention of many reformers and decision-makers in Europe. Meanwhile, within the context of a crisis-ridden socioeconomic environment, health inequalities constitute a persistent and egregious challenge, adversely affecting the health and well-being of a growing number of individuals and especially vulnerable population groups across Europe. ${ }^{2}$ Undoubtedly, as will be discussed in a later section of this paper, this alarming

* Lawyer, Supreme Court, Greece, Fellow, Global Health Law Groningen Research Center, Faculty of Law, University of Groningen, Netherlands. Email: ea.alexiadou@gmail.com

1. See European Comm'n Expert Panel on Effective Ways of Investing in Health, Typology of Health policy Reforms and Framework for Evaluating Reform EFfeCts (2016), https://ec.europa.eu/health/expert_panel/sites/expertpanel/files/013_healthpolicyreforms reformeffects_en.pdf [https://perma.cc/8X78-RYZA].

2. See, e.g., 2012 O.J. (C 199 E/04). See also, infra note 5. 
situation creates tension with health rights and the values they embody, primarily when a human rights dimension is largely absent from the formulation and implementation of any proposed type of health care reform. Perhaps, acknowledging the gravity of such concerns, the World Health Organization cautioned member states of their harmful implications for health and urged them "to ensure that their health systems continue to protect those most in need (the poor, the elderly, the sick and frail), to demonstrate effectiveness in delivering personal and population services, while cooperating with other sectors to encourage health equity considerations to be taken into account." 3

Hence, the present analysis sets out to address what human rights can bring to health care reforms: (i) by paying attention to principal human rights standards that frame state obligations concerning health care provision and (ii) by assessing health care reforms within particular European realities through a human rights lens. Arguably, this assessment aims to contribute to the social policy and political debate on the nature and scope of health care reforms, which concerns every country and every individual worldwide. Essentially, it intends to serve as a piece of discussion about the extent to which imposed health care reforms across Europe are complicit with human rights requirements and particularly with the right to health requirements. But first, the European dimension of socioeconomic health inequalities, an extensive challenge of our time, will be examined as crucial background information for the subsequent analysis.

\section{UNPACKING THE CONTEXT FOR HEALTH CARE REFORMS: THE CHALLENGE OF INEQUALITY ACROSS EUROPE}

Inequality within and between countries constitutes a global phenomenon, driven by neoliberal political and economic policies and ideologies, advanced capitalism and austerity regimes that tend to subordinate social goals and undermine social rights. ${ }^{4}$ In Europe, inequality took center stage in the political agenda in the aftermath of the Eurozone crisis and the subsequent implementation of reform measures with significant adverse implications on publicly provided social services, including healthcare, and human welfare in general. ${ }^{5}$ Arguably, inequality poses considerable risks to the life and health of individuals and groups, especially those in vulnerable situations, with long-lasting effects on their life course, while having a detrimental impact on economic development that goes across generations. ${ }^{6}$

3. World Health Organization Regional Committee for Europe Res. EUR/RC59/R3, \ 3 (Sept. 16, 2009).

4. See Economic and Social Rights in a NeOliberal World (Gillian MacNaughton \& Diane F. Frey eds., 2018); Audrey R. Chapman, Global Health, Human Rights and the Challenge of Neoliberal Policies (2016).

5. See, e.g., Rita Baeten, Slavina Spasova, Bart Vanhercke \& Stéphanie Coster, Inequalities in Access to Healthcare. A Study of National Policies (2018).

6. See id. See also Organ. For Econ. Co-Operation and Dev. Ctr. For Opportunity

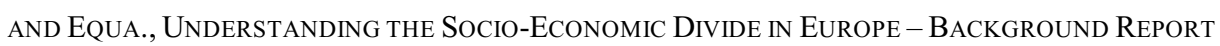


As is well established, over the course of the last decade and particularly since the onset of the 2008 financial crisis, which severely affected the European region, socioeconomic inequality within and between EU member states has intensified. ${ }^{7}$ In fact, a recent report by the Organisation for Economic Co-Operation and Development (OECD) affirms that the 2008 financial upheaval and the subsequent implementation of fiscal consolidation fueled a social crisis with "profound knockon effects on people's job prospects, incomes and living arrangements," added socioeconomic risks for vulnerable groups in society and long-term consequences in areas, like family formation, fertility and health; while the numbers living in households without any income from work, especially in those European countries hardest hit by the crisis, like Greece and Spain, highly increased. ${ }^{8}$ Meanwhile, despite weak financial recovery within the EU in 2016, poverty rates were relatively high in southern European countries, such as Greece, Spain, Italy, and Portugal at almost 15\%, while poverty in Denmark and Finland affected only 5-6\% of the population. ${ }^{9}$ Additionally, in 2016 life expectancy at birth in low-income European countries remained lower compared to that in high-income European countries, such as Sweden, Norway, and the Netherlands, where life expectancy almost reached 85 years. ${ }^{10}$ Nonetheless, these figures alone fail to capture the farreaching repercussions of inequality from one generation to the next.

Crucially, inequality constitutes the most pressing and enduring challenge facing certain population groups in Europe, with the most socially disadvantaged one being the Roma, the oldest and largest ethnic group in Europe. ${ }^{11}$ Indeed, for years the deep-rooted societal prejudices perpetuate Roma segregation from mainstream society and tend to erode any effort for positive change, primarily geared towards unimpeded access to public social services. ${ }^{12}$ Undeniably, the

(2017), https://www.oecd.org/els/soc/cope-divide-europe-2017-background-report.pdf [https://perma.cc/U3GB-GJWY].

7. See Organ. for Econ. Co-Operation and Dev. Ctr. for Opportunity and Equa., supra note 6. See also Organ. For ECON. Co-Operation AND DeV., SOCIETY AT A Glance 2014: OECD Social IndicAtors-The CRISIS AND ITS AfTERmath (2014), https://read.oecdilibrary.org/social-issues-migration-health/society-at-a-glance-2014_soc_glance-2014-en\#page1 [https://perma.cc/3ZJF-JMWX].

8. See Society at a Glance 2014: OECD Social Indicators-The Crisis and Its AFTERMATH, supra note 7, at 11 .

9. Org. For Econ. Co-Operation ANd Dev., Society at a Glance 2019: OECD Social INDICATORS-A SPOTLIGHT ON LGBT PEOPLE 100-01 (2019), https://www.oecd-ilibrary.org/ docserver/soc_glance-2019-en.pdf?expires=1577516238\&id=id\&accname= guest\&checksum=606CA3486BCA7DE233E9468E7176AE93 [https://perma.cc/WRL4-WLPT].

10. Id. at 110-11.

11. See The Situation of Roma in Europe and Relevant Activities of the Council of Europe, PARliamentary AsSembly (June 22, 2010), https://assembly.coe.int/nw/xml/XRef/XrefXML2HTML-en.asp?fileid=17875\&lang=en\# [https://perma.cc/833Q-WK6V]. See generally IAN F. Hancock, We Are the Romani People (2002).

12. See Amnesty Int'L, Briefing Human Rights on the Margins Roma in Europe 10 (2010), https://www.amnesty.org.uk/files/roma_in_europe_briefing.pdf[https://perma.cc/7JXA- 
historical prejudice and the stigmatization, compounded by the precariousness of life conditions and systematic marginalization from many aspects of daily life which most Roma in Europe experience, have considerable adverse implications for their health and human rights in general. ${ }^{13}$ As recent research has shown, Roma in Europe experience higher rates of mortality, especially infant mortality, and increased (avoidable) illness relative to majority population groups. ${ }^{14}$ Additionally, the high levels of poverty, unemployment in conjunction with unregulated civil status (i.e., lack of insurance and identity documents) among Roma intersect with their access to health care across Europe and constitute significant barriers for the Roma when seeking needed care. ${ }^{15}$ Similarly, grave concerns arise often in relation to Roma environmental matters, namely in terms of dire housing conditions and geographical segregation of Roma settlements. ${ }^{16}$ For example, a 2016 nine-country survey conducted by the EU Fundamental Rights Agency (EU-MIDIS II) noted that: (i) $80 \%$ of the Roma surveyed continue to live below the at-risk-of-poverty threshold of their country, with employment rates below the EU average, and (ii) approximately one in two Roma surveyed (41\%) felt discriminated against due to ethnic origin at least once in one of crucial areas of daily life (i.e., at work, in education, and in healthcare) within the past five years. ${ }^{17}$ Meanwhile, at this stage, it is essential to mention that other groups in Europe, such as undocumented

GKG6]; Council Recommendation, 2013 O.J. (C 378); Elisavet A. Alexiadou, Ethnic Diversity and Access to Healthcare from a Human Rights Perspective: The Case of the Roma in Europe, 25 Eur. J. HeAlth L. 261 (2018).

13. Thomas Hammarberg, Human Rights in Europe: No Grounds For COMPlacency 57-82 (2011). See generally HANCOCK, supra note 11; Alexiadou, supra note 12.

14. Matrix, Roma Health Report - Health status of the Roma population- Data COllection IN THE Member States of the European Union, 113-15 (2014), https://ec.europa.eu/ health/sites/health/files/social_determinants/docs/2014_roma_health_ report_en.pdf[https://perma.cc/A4NX-VER6]. See generally WorLd HEALTH ORG. REG'LOFFiCE for Europe, Improving the Health of Roma in the WHO European region: A New InITIATIVE OF THE WHO REGIONAL OfFICE FOR EUROPE (2012), https://web.ua.es/es/iudesp/ documentos/ultima-hora/who-european.pdf [https://perma.cc/G5QT-PL6U].

15. European Commission, Report on the Implementation of the EU Framework for National Roma Integration Strategies, at 9-10, COM (2014) 209 final (Feb. 4, 2014). See generally WORLd HEALTH ORG. REG'L OfFICE FOR EUROPE, supra note 14.

16. See European Union Agency for Fundamental Rights, Housing Conditions of ROMA AND TRAVELlers IN THE EUROPEAN UNION-COMPARATIVE REPORT (2009), https://fra.europa.eu/sites/default/files/fra_uploads/703-Roma_Housing_Comparative-final_en.pdf [https://perma.cc/N874-5C9W]. See also European Union Agency fOR Fundamental Rights, The Situation of Roma in 11 EU Member States-Survey Results at a Glance (2012), https://fra.europa.eu/sites/default/files/fra_uploads/2099-FRA-2012-Roma-at-a-glance_EN.pdf [https://perma.cc/YDB8-9QWF].

17. European Union Agency for Fundamental Rights, Second European Union Minorities AND Discrimination Survey: Roma-Selected findings, 9-11, 14 (2016), https://fra.europa.eu/sites/default/files/fra_uploads/fra-2016-eu-minorities-survey-roma-selectedfindings_en.pdf [https://perma.cc/KL49-P3M3]. See Alexiadou, supra note 12. 
migrants, endure analogously disadvantaged and harsh conditions in Europe especially in terms of exposure to high levels of poverty, social isolation and increased health risks - harmful to their health and well-being. ${ }^{18}$ Notably, considering this precarious reality, the European Parliament critically declared in its 2011 resolution that "in many EU countries equitable access to healthcare is not guaranteed, either in practice or in law, for undocumented migrants" and called EU member states to effectively tackle socioeconomic health inequalities with special efforts to ensure that socially disadvantaged groups in society are reached. ${ }^{19}$

All in all, such worrisome trends largely uncover that societal conditions compounded by austerity regimes, persistent patterns of exclusion and disadvantage on the grounds of racial, social, national or ethnic origin or other status, remain tightly bound with individuals' state of health as well as with the varying degrees of (health) inequalities. ${ }^{20}$ Thereto, socioeconomic health inequalities within and between European countries call for comprehensive state reforms that involve the development of enabling environments (e.g., favorable laws and policies), to combat structural imbalances in accessing healthcare that generate these inequalities and ultimately place health rights at the center of the law and policy agenda by focusing attention on more than cost-benefit and marketoriented measures. At a practical level, this requires radical and comprehensive health care reform efforts that tackle the root causes of growing health inequalities with much attention paid to the several surrounding socioeconomic aspects (e.g., poverty, social exclusion) which constitute the overall context within which these reforms are to be implemented. In essence, addressing the growing problem of inequality constitutes a crucial prerequisite for countering or at least significantly mitigating the worsening of financial and social hardships and adverse impact on the realization of health rights; and finally, for paving the way for securing the function of equitable and universal health care reforms across Europe.

\section{HUMAN RIGHTS STANDARDS}

Since the adoption of the first right to health provision in the 1946 WHO's

18. See Platform for International Cooperation on Undocumented Immigrants, Undocumented Migrants and the Europe 2020 Strategy: Making Social Inclusion a REALITY FOR All MigRANTS IN EUROPE (2015), http://picum.org/wp-content/uploads/2017/11/ UndocumentedMigrantsandEurope2020Strategy_EN.pdf[https://perma.cc/KFW7-8B8U. See also Elisavet Athanasia Alexiadou, The Right to Health. A Human Rights Perspective with a Case Study on Greece, 215-247 (2016) (PhD diss., Leiden Univ.).

19. European Parliament, supra note 2 q $\mathrm{AD}, 4$.

20. See generally Understanding Health Inequalities And Justice: New Conversations Across the Disciplines, (Mara Buchbinder, Michele Rivkin-Fish \& Rebecca L. Walker eds., 2016); Commission on Soc. Determinants of Health, Closing the GaP in a Generation: Health Equity Through Action on the Social Determinants of Health. Final Report of the Commission on Social Determinants of Health (2008), https://www.who.int/ social_determinants/final_report/csdh_finalreport_2008.pdf [https://perma.cc/4V6Q-EGS3]. 
Constitution, health rights are increasingly recognized in a world that is full of tensions and challenges, ranging from egregious inequality to economic recession and austerity regimes. ${ }^{21}$ Admittedly, such worrying developments affront each individual's inherent dignity, confirmed as the basis of human rights, as well as tend to erode strong political commitment to work towards the effective enjoyment of health rights. ${ }^{22}$ Nevertheless, states, as primary duty-bearers, cannot escape from their binding health obligations, well-embedded in treaty texts, under any circumstances. ${ }^{23}$ Health obligations have been firmly enshrined and elaborated in a number of international and regional (human rights) instruments as well as in national constitutions. ${ }^{24}$ As such, a system of legal health obligations is developed in virtue of which states have the prime and ultimate responsibility over the design, delivery, and regulation of healthcare in consistency with human rights requirements and particularly with right to health requirements. Most notably, within the United Nations (UN) human rights system health was first legally affirmed as human right under the right to health provision (Article 12) enshrined in the International Covenant on Economic, Social and Cultural Rights (ICESCR), that mandates states parties to progressively take steps towards, inter alia, the creation of conditions that would ensure medical service and attention for all in the event of sickness. ${ }^{25}$ This state obligation is also declared in other international human rights treaties that focus on specific population groups. For instance, Article 24 of the Convention on the Rights of the Child (CRC), explicitly requires states to ensure that no child is deprived of his or her right of access to health care services, involving the treatment of illness and rehabilitation of health. ${ }^{26}$

Meanwhile, UN bodies have drawn attention to the interpretation of health obligations by way of providing standards against which state performance within the healthcare domain can be assessed over time. In August 2000, the UN Committee on Economic, Social and Cultural Rights (CESCR), the oversight body for the ICESCR, adopted the General Comment No. 14 (GC No. 14) aiming to assist states parties with the implementation of their health obligations. ${ }^{27}$ In this regard, the CESCR has explicitly stressed in its GC No. 14 that states parties have

21. See Constitution of the World Health Organization, World Health Organization, https://www.who.int/governance/eb/who_constitution_en.pdf[https://perma.cc/F6RE-7YHL]. See also, e.g., sources cited infra note 33.

22. See, e.g., G.A. Res 217 (III) A, Universal Declaration of Human Rights, art. 1 (Dec. 10, 1948); International Covenant on Civil and Political Rights, Dec. 16, 1966, 999 U.N.T.S 171, pmbl; International Covenant on Economic, Social and Cultural Rights, Dec. 16, 1966, 993 U.N.T.S 3, pmbl [hereinafter ICESCR].

23. Charles. R. Beitz, The Idea of Human Rights 114 (2009).

24. See, e.g., U.N. Special Rapporteur Paul Hunt, The right of everyone to the enjoyment of the highest attainable standard of physical and mental health, U.N. Doc. E/CN.4/2003/58 (Feb. 13, 2003).

25. ICESCR, supra note 22, at arts. 12(d), 2(1).

26. Convention on the Rights of the Child, Nov. 20, 1989, 1577 U.N.T.S. 3.

27. Comm. on Econ., Soc. \& Cultural Rights, General Comment No. 14: The Right to the Highest Attainable Standard of Health, art. 12, U.N. Doc. E/C.12/2000/4 (Aug. 11, 2000). 
a duty to respect the right to health by ensuring that all persons have equal access to preventive, curative and palliative health services [emphasis added], while they are obliged to ensure appropriate legislative control over issues relating to private health sector provision. ${ }^{28}$ Interestingly, the Committee went even further by specifying the state obligation "to ensure the right of access to health facilities, goods and services on a non-discriminatory basis, especially for vulnerable or marginalized groups" as a first core and non-derogable obligation under the right to health. ${ }^{29}$

At the same time, the CESCR has particularly emphasized that health care facilities, goods, and services (ranging from preventive and rehabilitative health services to appropriate treatment of prevalent diseases, illnesses and disabilities) are required to be available in sufficient quantity, accessible (physically, - geographically, and financially_regardless of whether the services are publicly or privately provided, and without discrimination), acceptable (respectful of medical ethics and culturally appropriate) and of good quality (collectively called as AAAQ). ${ }^{30}$ In addition to the AAAQ framework, the CESCR made the further point that participatory (e.g., in the form of a social dialogue with affected individuals and groups) and accountability mechanisms (e.g., health sector reviews, patients' rights bodies, national human rights institutions, and courts) are also crucial procedural elements in health-related decision-making, implementation, monitoring and evaluation of policies in the health sector. ${ }^{31}$

Crucially, in its GC No.14, the CESCR endorsed and reiterated a view earlier expressed in the Alma-Ata Declaration that inequality in the health status of people both within and between countries is "politically, socially and economically unacceptable and is therefore, of common concern to all countries". ${ }^{32}$ Especially in circumstances of an economic and financial crisis, it is notable that the CESCR has repeatedly underlined that adjustment programs and austerity measures should not disproportionately affect disadvantaged and marginalized individuals and population groups. ${ }^{33}$ Such a statement is particularly important when it comes to equitable health care accessibility given that the imposition of economic reform

\section{Id. ๆๆ 33-35.}

29. $I d .9$ 43(a), 47.

30. Id. $\ 12$.

31. Id. $\uparrow \uparrow 11,17,34,43(\mathrm{f}), 54,55$, and 59. See also, High-LeVel Working Grp. ON the Health \& Hum. Rts. of Women, Child. \& Adolescents, World Health Org., Leading the Realization of Human Rights to Health and through Health (2017); Alicia E. Yamin, Beyond compassion: the central role of accountability in applying a human rights framework to health, 10 Health \& Hum. Rts J. 1 (2008); Helen Potts, Participation And the Right to the HIGHEST ATTAINABLE STANDARD OF HEALTH (2008).

32. Comm. on Econ., Soc. \& Cultural Rights, supra note 27, ๆ 38.

33. Letter from Ariranga G. Pillay, Chairperson, U.N. Comm. on Econ., Soc., and Cultural Rights, to States Parties on Economic, Social and Cultural Rights, 2 (May 16, 2012). See generally Comm. on Econ., Soc. \& Cultural Rights, Statement on Public Debt, Austerity Measures and the International Covenant on Economic, Social and Cultural Rights, U.N. Doc. E/C.12/2016/1 (July 22, 2016). 
measures, involving high payments for healthcare and especially the shift of healthcare costs to patients, tends to aggravate the existing vulnerability of particular individuals and groups in society, namely those who are often exposed to high levels of poverty and social exclusion, overtly leading to discrimination. ${ }^{34}$ Indeed, in addition to the CESCR, the UN General Assembly in 2012 explicitly affirmed the responsibility of states to direct action towards universal health care reforms, by requiring that:

[a]ll people have access, without discrimination, to nationally determined sets of the needed promotive, preventive, curative and rehabilitative basic health services and essential, safe, affordable, effective and quality medicines, while ensuring that the use of these services does not expose the users to financial hardship, with a special emphasis on the poor, vulnerable and marginalized segments of the population. ${ }^{35}$

Meanwhile, in General Comment No. 15 the UN Committee on the Rights of the Child broadly acknowledged the state obligation to ensure universal coverage of quality primary health services, including prevention, health promotion, care and treatment services, and essential drugs, as a core obligation for the realization of the children's right to health, from which states cannot derogate. ${ }^{36}$

At the regional level, the Council of Europe $(\mathrm{CoE})$ and the European Union (EU) have both adopted "human rights" instruments which impose, inter alia, distinctive health care requirements on states. The (Revised) European Social Charter (RESC, henceforth: the Charter) under the right to health provision (Article 11) declares, inter alia, the state's obligation to take measures associated with the appropriateness of the functioning of health care facilities and the effectiveness of health system reforms for the states to ensure that the overall system of health care is responsive to avoidable health risks and accessible to the entire population without discrimination. ${ }^{37}$ Crucially, in terms of economically accessible health care, the Charter specifies in Article 13(1) that the state has to:

ensure that any person who is without adequate resources and who is unable to secure . . . by his own efforts or from other sources, in particular by benefits under a social security scheme, be granted adequate assistance, and, in case of sickness, the care necessitated by his

34. Comm. on Econ., Soc., \& Cultural Rights, supra note 33; Comm. on Econ., Soc., and Cultural Rights, supra note 27, 919.

35. G.A. Res. 67/81, ๆ 8, 10 (Dec. 12, 2010).

36. Comm. on the Rights of the Child, General Comment No. 15 (2013) on the Right of the Child to the Enjoyment of the Highest Attainable Standard of Health, art. 24, ๆ 73(b), U.N. Doc. CRC/C/GC/15 (April 17, 2013).

37. European Social Charter (Revised), CouncIL OF Europe 7 (May 3, 1996), https://rm.coe.int/168007cf93 [https://perma.cc/BC6P-W6S5]; European Soc. Charter Secretariat, The Right to Health and the European Social Charter, Information Document, ILGA Europe 910 (March 2009), https://www.ilga-europe.org/sites/default/files/right_to_health_and_esc.pdf [https://perma.cc/7PP6-J882]. 
condition. ${ }^{38}$

Obviously, under this provision, the Charter takes an explicit stance for universal health care and equality in health and health care.

Nonetheless, over the last years, the European Committee of Social Rights (ECSR) - the body responsible for monitoring the application of the Charter - has acknowledged in its case law the substandard or even the denial of access to health care for socially disadvantaged population groups across Europe. ${ }^{39}$ Recently, in the case of Complaint No. 104/2014 lodged against the Czech Republic the ECSR held that "the health care system must be accessible to everyone, especially the health care should be available to all who require it, and free of charge to those without the necessary resources" [emphasis added]. ${ }^{40}$ Importantly, the Committee found a violation of Article 11 of the Charter, by critically arguing that the state measures "do not sufficiently ensure health care for poor or socially vulnerable persons who become sick" and encounter disproportionate health risks. ${ }^{41}$ At the same time, the Convention on Human Rights and Biomedicine and its explanatory report give substantive meaning to the right to equitable access to health care recognized in its Article 3 by requiring states to provide health care: (i) of appropriate quality, (ii) in accordance with the person's medical needs, (iii) with the absence of unjustified discrimination and (iv) at a satisfactory degree. ${ }^{42}$ Meanwhile, at EU level, the Charter of Fundamental Rights of the EU (CFREU)

38. European Social Charter Revised, supra note 37, at 8.

39. Additional Protocol to the European Social Charter Providing for a System of Collective Complaints, Council of Europe arts. 1-2, 5, 8(1) (Nov. 9, 1995), https://rm.coe.int/ CoERMPublicCommonSearchServices/DisplayDCTMContent?documentId=090000168007 cdad [https://perma.cc/GVE7-SN85]; European Social Charter (Revised): ETS No. 163, supra note 37 at art. 25. See, e.g., European Comm, on Soc. Rights, No. 48/2008 European Roma Rights Centre (ERRC) v. Bulgaria, COUNCIL OF EUROPE, https://www.coe.int/en/web/european-social-charter/ processed-complaints/-/asset_publisher/5GEFkJmH2bYG/content/no-48-2008-european-romarights-centre-errc-v-bulgaria?inheritRedirect=false [https://perma.cc/ST7G-NTTH]; European Comm, on Soc. Rights, No. 151/2017, European Roma Rights Centre (ERRC) v. Bulgaria, COUNCIL OF EUROPE, https:/www.coe.int/en/web/european-social-charter/processed-complaints//asset_publisher/5GEFkJmH2bYG/content/no-151-2017-european-roma-rights-centre-errc-vbulgaria?inheritRedirect=false [https://perma.cc/VT7U-A4ZT].

40. European Comm, on Soc. Rights, European Roma and Travellers Forum (ERTF) v. the Czech Republic, Complaint No. 104/2014, CounCIL OF Europe 117, https://hudoc.esc.coe.int/ eng\#\{"ESCDcIdentifier":["cc-104-2014-dmerits-en"]\} [https://perma.cc/SK58-LH8N].

41. Id. ๆๆ 119-120.

42. Convention for the Protection of Human Rights and Dignity of the Human Being with regard to the Application of Biology and Medicine: Convention on Human Rights and Biomedicine, COUNCIL OF EUROPE 2 (April 4, 1997), https://rm.coe.int/168007cf98 [https://perma.cc/SY9V-SVUC]; Explanatory Report to the Convention for the Protection of Human Rights and Dignity of the Human Being with regard to the Application of Biology and Medicine, CouncIL OF EuROPE I 23-27 (April 4, 1997), https://rm.coe.int/16800ccde5 [https://perma.cc/42R3-9ZU2]. 
recognizes in Article 35 the right of everyone to access preventive health care and to benefit from medical treatment, ${ }^{43}$ while the Treaty on the Functioning of the EU (TFEU) in Article 168(1) provides that "a high level of human health protection shall be ensured in the definition and implementation of all Union policies and activities." 44

Last but not least, growing awareness of the long-term impacts of the recent Eurozone crisis on the social dimension of Europe has led to the establishment of the European Pillar of Social Rights, a soft law instrument that is addressed to all EU member states. ${ }^{45}$ The Pillar enshrines twenty principles and rights to enhance the functioning of welfare systems across Europe, and it is structured around three main categories, including social protection and inclusion. ${ }^{46}$ In fact, the social protection and inclusion category entails the right to timely access to affordable, preventive and curative health care of good quality (Pillar 16) as well as the right to affordable long-term care services of good quality, in particular home-care and community-based services (Pillar 18). ${ }^{47}$

Arguably, by setting out a number of standards and principles, these international and regional (human rights) instruments call attention to state obligations to realize health rights for all and at all times. Essentially, they bring into play an overarching framework primarily directed to state action, namely, requiring states to move their actions towards a greater focus on universal health care reforms, with an immediate and ultimate goal of complying with their health obligations and achieving optimum health for all, while effectively tackling the challenge of inequality. In fact, it is within this context that WHO pointedly notes that universal health coverage "is, by definition, a practical expression of the concern for health equity and the right to health. ${ }^{48}$ Hence, a crucial and pressing question remains as to how such a concern is addressed in the national context.

\section{LESSONS FROM EUROPEAN REALITIES}

In its long history, Europe has the oldest human rights system whose aim is to uphold respect for human rights, democracy, fundamental freedoms, and the rule of law. ${ }^{49}$ In relation to health and health care, all EU countries are parties to at

43. 2012 O.J. (C 326/02) 402. Of note, the Charter became legally binding with the entry into force of the Treaty of Lisbon on December 1, 2009.

44. 2012 O.J. (C 326/01) 122.

45. Communication from the Commission to the European Parliament, the Council, the European Economic and Social Committee and the Committee of the Regions: Establishing the European Pillar of Social Rights, COM (2017) 250 final (Apr. 26, 2017).

46. Id. at 4. See also 2017 O.J. (C 428/09).

47. C 428, supra note 46, at 14 .

48. Positioning Health in the Post-2015 Development Agenda: WHO Discussion Paper, World Health ORG. 3 (Oct. 2012), https://www.who.int/topics/millennium_development goals/post2015/WHOdiscussionpaper_October2012.pdf [https://perma.cc/S5XX-CK9Q].

49. See Henry J. Steiner, Philip Alston \& Ryan Goodman, International Human Rights in Context- Law, Politics and Morals, 925-27 (Oxford Univ. Press 3rd. ed. 2008). 
least one legally binding human rights treaty which guarantees a right to health (care) for every individual. Over the years they have enacted several pieces of national legislation that promoted the development of the traditional welfare state model in Europe ${ }^{50}$ Interestingly, from very early on, health care reform efforts have been an issue of policy concern at the Council of Europe level. For instance, in its 1626 recommendation, the parliamentary assembly of the Council pointedly stressed that "the main criterion for judging the success of health system reforms should be effective access to health care for all without discrimination, which is a basic human right. This also has the consequence of improving the general standard of health and welfare of the entire population." ${ }^{\text {"51 }}$ Nevertheless, despite important steps forward to universal health coverage of health insurance or national health systems, Europe seems to be moving away from the language of human rights commitment - particularly of right to health commitment — to one of technical inputs and efficiency gains ${ }^{52}$ Indeed, austerity regimes have emerged in many European countries that build crisis-ridden health care reforms on an exclusive focus that largely lacks a rights perspective. Admittedly, especially since the recent Eurozone crisis, the national health policy agenda of several European countries has been dominated by calls for curtailing public health care expenditure, de-listing medical services from social insurance packages, health care privatization, and cost-shifting to patients. ${ }^{53}$

Indeed, during the early years of the Eurozone crisis, the European countries worst hit by the crisis (e.g., Greece, and Portugal), entered into financial assistance programs in the form of Memorandum of Understandings (MoUs). These involved, inter alia, the adoption of substantial health care reforms largely associated with radical reductions in public expenditures for social services. ${ }^{54}$ For instance, in the case of Greece, the state generated a number of health care reform measures at the expense of equality in health and health care with major impact on the health system of the country — wedded to universal health care under Law 1397/1983. ${ }^{55}$

See generally Aart Hendriks, The Council of Europe and Health and Human Rights, HEALTH AND Human Rights in Europe, 23-50 (Brigit Toebes et. al. eds., 2012).

50. For instance, all European Union countries are parties to the ICESCR. See International Covenant on Economic, Social and Cultural Rights, United Nations Treaty Collection, https://treaties.un.org/Pages/ViewDetails.aspx?src=TREATY\&mtdsg_no=IV$3 \&$ chapter=4\&clang=_en [https://perma.cc/S8RL-QU5H]. See, e.g., Alexiadou, supra note 18, at 53-55. See generally Pierre Pestieau, The Welfare State in the European Union:EConomic AND SOCIAL PERSPECTIVES (2006).

51. Eur. PARL. Ass., Recommendation 1626: The Reform of Health Care Systems in Europe: Reconciling Equity, Quality and Efficiency, 30th Sess., ๆ 4 (2003).

52. See European Comm'n Expert Panel on Effective Ways of Investing in Health, supra note 1 , at 37.

53. Id. See Health Law: Solidarity and Justice in Health Care, 7-14 (A.P. den Exter ed., 2008).

54. See European Commi'n Expert Panel on Effective Ways of Investing in Health, supra note 1 , at $39-40$.

55. Alexiadou, supra note 18 , at 171-202. 
Principally, the public expenditure on health drastically curtailed; public healthcare facilities (i.e., public hospitals and rehabilitation care units), even though merged, remained critically understaffed and underfunded; increased co-payments and high prices in medicines were imposed; welfare programs reduced, seriously threatening the sustainability of social policies that provided a safety net towards certain vulnerable groups in society, often disadvantaged in terms of health outcomes and service coverage. ${ }^{56}$ As a consequence, the overall function of the public health system further deteriorated, placing an excessive burden on healthcare availability and accessibility. ${ }^{57}$ Notably, in terms of per capita health spending, Greece faced four consecutive reductions from 2009 onwards, namely -10.9\% in 2009-10, $2.8 \%$ in $2010-11,-12.2 \%$ in $2011-12,-2.5 \%$ in $2012-13 .{ }^{58}$ Surprisingly though, in 2013, parallel to the imposition of several health care austerity measures and in response to the European policy for health and well-being, Health 2020 - and perhaps given the implications of widening inequalities in access to health care-Greece decided to seek the assistance of WHO. Its intention was to reform its health system in order to actually achieve universal access to high-quality health services; with the explicit attention to the extremely poor and disadvantaged as well as with primary health care to be the cornerstone of this national reform initiative. $^{59}$

At the same time, another noticeable shift that occurred in several European countries pertains to the proliferation of health sector privatization. The growing public health care costs in Europe compounded by a conjunction of demographic (European population aging), economic (long-lasting recession), and technological (medical advances) challenges immensely pushed privatization in health sector provision forward. ${ }^{60}$ In the case of the Netherlands, for example, from 2006 onwards, imposed health care reform measures concerned the restructuring of the country's health system through the introduction of a decentralized private health insurance system with regulated competition - under the supervision by independent authorities - while ensuring universal coverage with subsidies for poor and vulnerable groups. Particularly, health insurance companies were transformed into private entities, selectively contracting with health care providers with the

56. Id. See, e.g., Comm. on Elimination of Racial Discrimination, Concluding Observations on the Twentieth to Twenty-Second Periodic Reports of Greece, q1 6-7, U.N. Doc CERD/C/GRC/CO/20-22 (2016). See generally Giannis Sakellis, Social Protection in ANNUAL REPORT 2010- GREEK OMBUDSMAN, $57-75$ (2010) https://www.synigoros.gr/resources/docs/ annual_2010.pdf.

57. Id.

58. Org. Econ. Coop. \& Dev., Focus on Health Spending - OECD Health Statistics 20154 (2015), https://www.oecd.org/health/health-systems/Focus-Health-Spending-2015.pdf [https://perma.cc/B772-9PSN].

59. See WHO, Greece Sign Agreement on Support Programme for Health Reform, WoRLD Health Org. Reg'L OfF. Europe (Feb. 7, 2013), http://www.euro.who.int/en/countries/greece/ news/news/2013/07/who,-greece-sign-agreement-on-support-programme-for-health-reform [https://perma.cc/6H5Q-686Y].

60. See Health Law: Solidarity and Justice in Health Care, supra note 53. 
intention of cost-containment and maximizing efficiency. ${ }^{61}$ In a similar vein, since 2006 Sweden has undergone significant market-oriented health care reforms through the gradual sell/transfer of public hospitals and primary health care services to private providers. ${ }^{62}$

The preceding analysis invites the following observations in relation to the nature and scope of system reforms developed across Europe over the course of the last years. Crucially, European countries tend to adopt health care reforms mostly involving deep public health care budget cuts, the imposition of cost-containment measures on social welfare and health, and the gradual transfer of health care services to the private sector, while at the same time retaining universal health coverage at least in principle. In a way, the calls for imposing mainly economic reform measures (market-based reforms) - at the expense of tackling socioeconomic health inequalities that exist across European countries and regions as well as between population groups, as previously mentioned - highly reveal the weaknesses of European health systems in responding to a variety of pressures and challenges in accordance with human rights commitments. Even though not all the implications of the imposed health care reforms are yet known, it is clear that the growing concern about poorer households and socially disadvantaged groups in Europe has not been yet matched by comprehensive national reform efforts. Some steps have been taken towards alleviating (financial) hardships (e.g. in the form of state subsidies), but affordable and equitable access to health care is still lacking and more must be done.

Meanwhile, it is plausible to discern that these predominantly crisis-ridden health care reforms do not reflect a progression but tend to cause a regression in the realization of health rights, which is of major concern from a human rights perspective and requires more considered state attention to challenge its key elements. Essentially, as emerged from the analysis, the imposed health care reforms signal dangers for the ability of individuals and groups to exercise their right to health, while at the same time, aggravate existing inequalities by placing disproportionate (financial) barriers to health care access for poor and socially disadvantaged groups that are often vulnerable in terms of health outcomes and coverage. In fact, health care reforms based on the privatization of health care provision have raised a human rights concern in that the choice of privatization as a health care reform measure can be detrimental to the equitable availability and accessibility of health care, especially when this reform initiative is poorly conceived and under-regulated by a state.$^{63}$ Nonetheless, it must be conceded that regulated health sector privatization with substantial and sustained insurance subsidization for disadvantaged groups in society is possible to create a window

61. See generally Brigit Toebes \& Maite San Giorgi, Dutch Realities: Evaluating Health Care Reform in the Netherlands from a Human Rights Perspective, in THE Right TO HeALth: A Multi-Country Study of Law, Policy and Practice 403-436 (Brigit Toebes et al. eds., 2014).

62. See Göran Dahlgren, Neoliberal Reforms in Swedish Primary Health Care: For Whom and for What Purpose?, 38 INT'L J. HEALTH SERV. 697 (2008).

63. U.N. Secretary General, Right of Everyone to the Enjoyment of the Highest Attainable Standard of Physical and Mental Health, ๆ 3, U.N. Doc A/67/302 (Aug. 13, 2012). 
of opportunity to cover inefficiencies in the public health sector, such as to enhance timely access to quality health care. ${ }^{64}$

Overall, irrespective of differences in reform patterns, legal traditions, cultures, political context and resource capacities, concrete lessons can be learned from the experiences of European countries that could be relevant to other countries worldwide, facing health inequalities and health system deficiencies. Undoubtedly, European realities call for a state focus on taking these lessons forward with the twin aim of protecting and enhancing population health while guaranteeing universal health coverage and substantive equality in access to health care for every individual.

\section{CONCLUSIONS: LOOKING AHEAD}

From the preceding analysis, it can be observed that the nature and scope of health care reform measures and especially their adherence to human rights standards constitute a significant determinant of equitable access to health care. In fact, framing health care reform measures in a manner inconsistent with human rights standards contributes to the reproduction of inequality in health and health care, predominantly harming poor and socially excluded households whose voices are often not heard and whose pressing health needs are not met. To remedy this disturbing trend in increasingly diverse societies, states should shift the focus of their attention to the inclusion of pressing health needs and challenges of all social classes and especially marginalized ones in the formulation and implementation of their health care reforms. To this aim, a system needs to be set up that ensures that imposed health care reforms reach the goal of universal coverage on the one hand and system efficiency on the other. This requires the adoption of a national framework law: (i) articulating stringent and salient human rights standards that will serve as guideposts for the deliberations about the nature and scope of health care reform measures by directing priority attention to the most vulnerable in society; and (ii) identifying tangible human rights commitments to be implemented by all responsible health sector actors, state, and non-state actors, so as to be employed by individuals and/or groups as a means for redress once their health rights are violated. ${ }^{65}$

Nonetheless, it must be conceded that human rights standards do not provide easy solutions on health care reform choices, while no "one-size-fits-all" planning approach is available that will be achieved at once. Looking ahead, it is therefore essential that the performance of any national health care reform effort be continuously monitored, evaluated and informed by discrete national realities, pressing needs and challenges, for the states to ensure that health care reform practices take due account of human rights norms; are sensitive to national circumstances (e.g., socioeconomic health inequalities, poverty); and are neither exclusively profit-driven nor crisis-ridden, but resilient to deal with existing and future crises and challenges. Indeed, as Eleanor Kinney has pointedly argued more

64. Alexiadou, supra note 18 , at 206.

65. See Alexiadou, supra note 18 , at 295-300. 
than a decade ago "the international human rights to health . . . arguably impose greater obligations on the United States and other nations with respect to health than we currently appreciate or recognize". ${ }^{66}$ With this in mind and without doubt, the lesson seems to be that when explicit human rights commitments and effective state action coincide - in other words when there is a robust political will to do so - the enactment of substantial health care reforms to the benefit of society is possible.

66. See Eleanor D. Kinney, The International Human Right to Health: What does this mean for our Nation and World?, 34 IND. L. REV. 1475 (2001). 